\title{
Newly wed in Wittenberg 1523 - And committed to the Lutheran Reformation
}

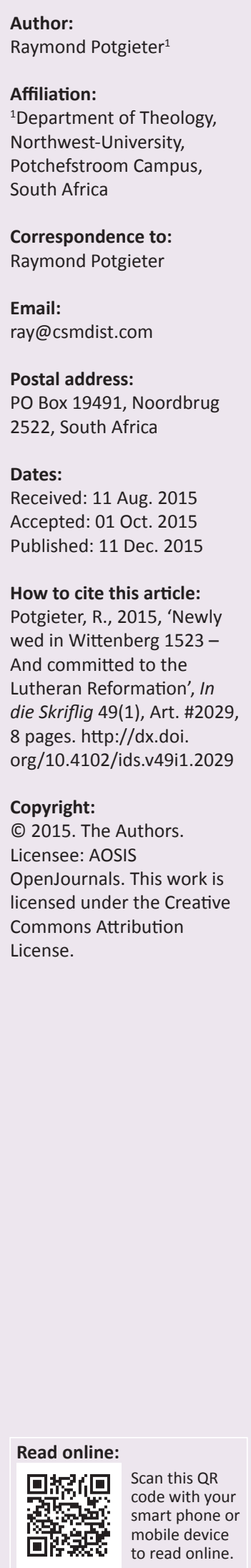

Protestant teaching questioned the redemptive value of Roman Catholic spirituality of the 16th century. Consequently many monks and nuns were led to leave their monasteries and convents. Elisabeth von Meseritz was a nun who found her way to Wittenberg. There she married and wrote the first protestant hymn as a woman clearly supportive of the Lutheran Reformation. The simplicity of Elisabeth's story is a projection from one major event of her life to another ignoring the complexity of contexts and influences upon her which continued to shape her life. Instead of only focusing on the obvious highpoints of her story this article allows for the development of a fuller story that enriches understanding of an early protestant of the 16th century, a woman of the Lutheran Reformation.

Pas getroud in Wittenberg 1523 - en toegewyd tot die Lutherse Reformasie. Protestantse leerstellings het die heilswaarde van die Rooms-Katolieke spiritualiteit van die sestiende eeu bevraagteken. Baie monnike en nonne het gevolglik hulle kloosters verlaat. Een van hulle was Elisabeth von Meseritz wat haar pad na Wittenberg gevind het. Daar is sy getroud en het die eerste protestantse lied as 'n vrou geskryf wat duidelik ondersteunend van die Lutherse Hervorming was. Die eenvoud van Elisabeth se storie is 'n projeksie van die een belangrike gebeurtenis van haar lewe na die volgende. Dit het die kompleksiteit van die konteks en die invloede wat voortgegaan het om haar lewe te vorm, geïgnoreer. In plaas daarvan om net op die voor die hand liggend hooftrekke van haar storie te fokus, maak hierdie artikel voorsiening vir die ontwikkeling van 'n verrykende storie met begrip vir die vroeë Protestantse sestiende eeuse vrou van die Lutherse Hervorming.

\section{City reformation and early gender issues}

Much of the Reformation of the early 16th century was localised in cities. A distinction may be made from the larger generic national or regional reformations. Moeller (1972:15) proposed that 'Die deutsche Stadt des Spätmittelalters hat eine Neigung, sich als corpus christianum im kleinen zu verstehen'. ${ }^{1}$ Suggestibility of religious and directional change was more evident within the city than outside of it. Social historians have challenged the traditional narratives of the Reformation and the story of the city. They claim that conversation from doctrinal perspectives alone deprecates or even ignores insights of a social environment. Whitford (2012:3) recently continues this doctrinal fixation as he introduces his essay on the Reformation persuaded that 'the European Reformation was primarily a religious event driven by theological concerns'.

Consequently new slants introduced to the accepted narrative challenged monocausal attempts so as to capture more of the narrative's complexity (Holt 2003:133, 135). ${ }^{2}$ This approach allowed for a shift in emphasis from the concerns of and what the major reformers believed to lay perceptions of the day and of women, and in the process the understanding of the Reformation was enriched. ${ }^{3}$

Social exploration generated new interest regarding the cities of the Reformation. Progress of Lutheran theology within the confines of the city limits became the dynamic theology of its citizens, especially evident in the 'free cities' (Classen \& Settle 1991; Moeller 1972:60). ${ }^{4}$ This does not mean that a blend of civic ideology and reformed confession (Po-Chia Hsia 1987:215)

1.'The German city in the later Middle Ages tended to view itself in miniature as a corpus christianum' (interpretation - RP).

2.Much more was at stake though, such as that the Reformation replaced outdated superstition and religion, and studied the socially constructed groups who were to support these traditional claims (Holt 2003).

3. Holt (2003:136ff.) is not unaware that divorced from doctrine the emphasis on social issues leads to general religion and so to a loss of reformational distinctives.

4.Moeller (1972) suggests that the contrasts of impact of the Reformation on cities in the north (free cities) and south (imperial cities) of Germany will add to the understanding of the degree of acceptance of the movement and its impact. 
became a dominating influence and an attempt to question the reformed confessions. Rather a synergy developed as the Reformation found its principles tested and applied in the warp and woof of society; the peace of Augsburg and of Westphalia in fact brought about bi- or even tri-confessional communities (Po-Chia Hsia 1987:214).

Gender issues in these early reformation cities were already evident. Despite their numbers in the cities, which often eclipsed the male population, women were generally excluded from formal involvement in civic structures and processes (Po-Chia Hsia 1987:215). Social problems come more to the fore when matters such as poverty and family histories are seen to reflect the plight of all the stake holders (children, men, women, infirm, aged, unemployed, etc.). Despite this it was also the age of the querelle des femmes (debate of or about women); views were opined by Erasmus, John Knox, and of course Martin Luther. Views about women covered a spectrum of subjects, viz. marriage, sexuality, family, institutional changes, to name a few. Luther's views on women and associated topics 'fill several long volumes' in biblical commentaries, sermons, tracts, lectures (KarantNunn \& Wiesner-Hanks 2003:4). Nevertheless, as Spierling (2012) states:

The leading male reformers' views of women, their nature, and their proper God-given roles had immediate social relevance and helped to circumscribe the participation of women in shaping the Reformation during the sixteenth century and later. (p. 179)

Spierling (2012:179, 180ff.) also makes the point that the leading reformers' publications were not discussions of women but dedicated to the debate about them.

This article mainly seeks to trace the lifestory of Elisabeth Cruciger who found herself in Wittenberg ${ }^{5}$ by choice and became part of the new theology (Lutheran), that infected everyday life including that of the role of women and their place in society and religion.

\section{Women in the Reformation era, makers ${ }^{6}$ of their own history Women in the city or convent}

Traditionally the household of early modern Europe was patriarchal, the man as husband and father ruled the household and served as provider (Hendrix 1995:177). A man was called to duties beyond the home, such as to civic and church leadership, because he managed his home well. Women could be partners in business and work alongside their husbands, share in the affection one for the other and for their children (1995:178). The influence of the Reformation leads to the perception and expectation of change in the

5.Wittenberg incorporates the name of its Saxon founder, Wittekind, the younger (cf Aikin 1989:28).

6.I am well aware of the multiplicity of social adaptations to include dimensions as diverse as culture, politics, finances, worship and so on. Social adaptation in this article will generally apply to its all-inclusive generic form unless stated otherwise. community due to the influence of this new theology. ${ }^{7} \mathrm{~A}$ reformer's household would centre around the couple, and could include their married children, grandchildren, orphans, visitors, guests and scholars. There was little Lutheran protestant emphasis on the masculinity of men taking on a domestic or civic role, in that respect they 'stayed under cover' (1995:180). Women, born into higher station, could enter power structures allowing for public voice, but the lower echelons of society actually saw a decline of their influence when entering into protestant social and ecclesial structures (Classen \& Settle 1991:232). Nevertheless there was little doubt that the new faith, accompanied by action, supported the belief that God was sovereignly at work in all spheres of life, the end being a redemptive society (Potgieter 2014:3).

Women often entered convents because of men's decisions (Harris 1993:112). But once in, a diminished patriarchal authority came into play. An abbess could, for instance refuse to convert her convent to Protestantism in spite of ducal or ecclesial pressure (Hendrix 1995:178). There was immense freedom for women in convents and recent research dispels much of the view that nuns were oppressed in a dominant patriarchal order (Harris 1993:89, footnote 1:90). Expression of their freedom fostered independent identities evident in their particular public and private ministries. When protestant reformers exerted their influence on convents nuns began to explore the ideas preached. It was especially the notion of the priesthood of believers ${ }^{8}$ that resonated with women in convents (Spierling 2012:180). However, upon leaving nunneries women found that in spite of new doctrinal insights, reformation churches did not cater for a continued identity of these independent women or their particular spirituality. Rather they faced limited options. ${ }^{9}$ Many simply chose to be reintegrated into the 'family' identity of domesticity and implicitly into ecclesial roles (diaconal or cure) within a community without much public recognition. That there was an especial narrowing of choices for women were more evident where more overt evangelical emphases (Karant-Nunn \& Wiesner-Hanks 2003:10) were stressed. In the light of the aforementioned Classen and Settle (1991:231) suggest that the actual social role of women of the 16th century needs more exploration.

In facing decisions of domestication women also faced 'the beast of sexuality that had always haunted the sacrament of marriage and had forever tainted the act of procreation with the sin of lust ${ }^{\prime 10}$ (Holt 2003:137). From the marriage pamphlets

\footnotetext{
7.At least ten German protestant clergy wrote a number of pamphlets pertaining to marriage at the time. Hendrix (1995:179) mentions that nine of the clergy had been former priests or monks, Veit Dietrich being the single exception. The pamphlets in the main dealt with five topics, viz. Sexual vulnerability of men; Sexual expression and restraint; The burdens of marriage; The benefits and costs of support; Blame and consideration (Bainton 2013:307ff.; Hendrix 1995).

8.Not only was the role of women uncertain but even that of men within this doctrine, viz. the accusations of Anabaptists with Lutheran emphasis on ordination (Scribner 1987:126).

9.Spierling (2012:180ff.) suggests that Lutheran theology impacted the 1520 s manifestly but partially in some areas.

10. Historically the matter was generally related to Augustine's De civitate Dei, books 13 and 14 (Holt 2003:137)
} 
of the day it is evident that men were regarded to be sexually vulnerable and needed 'sexual expression and restraints on that expression' (Hendrix 1995:181). To a large degree the poor track record of the Roman church's 'celibate priests' (Hurenpfaff $=$ whore priest $)$ and monks led to this skewed view. Nevertheless in protestant circles failure in marriage, such as in failing to provide for one's family, also made men more vulnerable to blame (1995:181). Protestantism developed a more tolerant approach to remarriage and sanctioned divorce in cases of spousal abandonment and adultery. Holt (2003:138) queries whether these laws benefitted women positively. Nevertheless the views of marriage and the role of mutual love began to supersede paternal negotiations; often for the purposes of mutual advantage through notions of political advantages and accrual of property.

\section{Some background to the development of Luther's theology on marriage}

Erikson's psychobiography of the young Martin Luther (1993) is a psychological analysis which follows the theme that Luther's story centres on an identity crisis, ${ }^{11}$ from which he never seemed to escape fully. This most clearly manifests in his authoritative ${ }^{12}$ control of matters (McAdams 1988:66). For that reason he argues that Luther's theology on, for instance marriage cannot be solely interpreted as a masculine story. Luther was never free from patriarchalism - man is the head of the wife; justified theologically by virtue of the order of creation though allowing ${ }^{13}$ for expression within her own sphere (Bainton 2013:306).

\section{Elisabeth von Meseritz and her gender story}

Insight from Gilligan (1982) suggests that masculinity may be directly related to an emphasis on principles of rights and on justice whilst a more interpersonal approach leans on a feminine orientation. Identity ${ }^{14}$ is actually a story in the making in general comparable to a person's life (1982:17). Let me explain: Lifestory connects the dramatic scenes and turning points, establishment of beliefs which all form the plot line of a person's lifestory (McAdams 1988:40ff.). ${ }^{15}$ But from this perspective it does not particularly emphasise personality (1988:60).

This generic lifestory model may also be applied to Elisabeth Cruciger's lifestory as well. For the sake of brevity this will not be a lifescript focusing on repetitive scenarios cluttering a lifestory, but will follow a more ontological approach to

\footnotetext{
11.Purported to have invented or at least first used the term probably because it emerged from his own personal crises.

12.Implicit is control to the extent of being dictatorial.
}

13.Zook (2002:373, 381-382) makes a case for gendered history, distinguishing between women's and men's histories showing how each conformed throughout history.

14.'Identity is more than ideology' and may develop into a lifestory model. This may be developed, with more complexity than necessary for this article, along four major components: 'nuclear episodes', 'imagoes', 'ideological setting', and 'generativity script' (McAdams 1988:36, 60ff.; cursive in the original).

15.McAdams follows a psychoanalytic approach using lifestory, whereas Plato viewed story as a step(s) removed from reality and thus the truth (McAdams 1988:51; cf. The Republic, bk. 7). the self. Significant historical events of her lifestory will be mentioned in brief with reference to some societal dynamics of her environment, the city. These will help to serve to identify the person she was and why she did things that way. ${ }^{16}$ This generic approach will not test the complexities of the lifestory model ${ }^{17}$ but should serve to give some insight into the role of a woman persuaded by the Lutheran reformation, first in a convent and then in Wittenberg.

\section{Elisabeth Curciger (1500?-1535), ${ }^{18}$ née von Meseritz and the preaching that caused a stir in the convent leading to a decision}

A geographical stretch of land adjoining the sea and situated between Germany and Poland was historically known as Pomerania, ${ }^{19}$ a Prussian domain in the 16th century. A prominent Pomeranian family lived in the town of Meseritz, in farther Pomerania, the birth place of Elisabeth von Meseritz (Stjerna 2009:186).

Elisabeth did not simply enter Marienbusch Abbey in Treptow an der Rega (today Trzebiatów) and then leave for Wittenberg. There is far more to the story than that. There is background that should be taken into consideration. The abbey was closely situation to the monastery of Belbuck (also known as Belbuk) situated on the hill dominating the town of Treptow an der Rega. Its austerity and pastoral ministry in parishes close by was a shared ministry by monks and nuns on equal footing in accordance with its premonstratensian ${ }^{20}$ persuasion. Elisabeth von Meseritz served in keeping with premonstratensian practice. She also received an education in Latin and biblical interpretation. Abbot Bodewan, appointed in the same year that Luther nailed his theses to the Wittenberg door (1517), was already committed to reform the monastic life of the abbey, concerned about moral and religious laxity. To that end he established a chair of lectures and invited a canon of Treptow, Johannes Bugenhagen, to lecture (1517) regularly on the Bible (Ruccius 1925:15-16). Bugenhagen was 'an earnest, severe, vigorous reformer, but quite content to nestle on the bosom of the Church' $(1925: 12,19)$.

In 1504 Johannes Bugenhagen ${ }^{21}$ (1485-1558), became rector of a local city school ${ }^{22}$ and was known for his teaching and

16.I will not extend this article to include lifestory in its metaphorical sense, though this obviously may lead to some interesting insights about Elisabeth Cruciger. McAdams (1988:60ff.) has some insightful suggestions for this approach.

17. Hendrix (1995), for instance suggests a masculine taxonomy arising from the pamphlets on marriage by protestant preachers during the Lutheran Reformation in Germany, viz. sexual vulnerability, sexual expression and restraint, the burdens of marriage, the benefits and the costs of support, blame and consideration.

18.The names referred to vary in spelling, for instance Elisabethe, Kreuziger, Creutziger, Crützigeryn, Cruziger, Crucigerin.

19.Pomerania is generally referred to as Pomorze in Polish and Pommern in German.

20.Formerly known for its austerity the order was founded by St. Norbert in 1120 . He was of noble birth, ascetic and charismatic. Though committed to the Rule of St. Augustine it was also influenced by the Cistercian rule, probably because of its founder's Benedictine ties. Six preachers emerged from this group of Premonstratensians, one of whom was Abbot Bodewan (Scribner 1987:127; cf. footnote 12).

21. He was affectionately called Doctor Pomeranus by Luther. He was called the 'second apostle of the north' (Ruccius 1925) but not the only one accorded that title, for example also Sigfrid of Sweden and Unni (cf. http://en.wikipedia.org/wiki/ Unni_(bishop)).

22.Bugenhagen became known as the father of the Volkschule. 
organising abilities (Ruccius 1925:3, 11). He was ordained in 1509 by the Bishop of Cammin and installed as minister of the Church of St. Mary's, Treptow. With some of his friends attending Wittenberg University (founded in 1502) and after reading Luther's Praeludium de Captivitate Babylonia Ecclesiae [Babylonian captivity] $^{23}$ in 1520, he became a follower of Luther learning that the Scriptures are not law and gospel but primarily gospel (1925:22). He left for Wittenberg in 1521, aged 36 years. He became renowned for being a reformer. By 1534 Lutheranism was a significant influence not only in Treptow but in Pomerania as well having the support of it rulers, Dukes Barnim XI and Philip I. This led to the founding of the Pomeranian Lutheran church ${ }^{24}$ following the Treptow an der Rega Common Diet of 1534.

Reformational preaching attacked the Roman Catholic Church's interpretation of spirituality. It exposed the socalled mystical power and efficacy of the eucharist and any redemptive value of prayer and sacrifice (McNamara 1996:419). This must have cut deep into the heart of the listeners in convents and monasteries and by implication that of Elisabeth von Meseritz. Celibate monastic life and sacrificial service were no longer associated with intercession for souls and a sharing in the passion of Christ (1996:420).

New alternatives for ministry were preached. These days of early Reformation were without an institutionalised church and so with the promise of the priesthood of believers 'renegade' nuns eagerly sought opportunities 'to play a more pastoral role' in communities (McNamara 1996:420). Reality, however, conflicted with such an ideal. In truth they met with predominantly male leadership who were wrestling with the processing and developing of theology which would later concretise in formal ecclesial structures..$^{25}$ Another tension that came about was that internal monastic learning, which was monopolised by clergy, was now being replaced by university educated lecturers who challenged existing ideas proposing biblical models as replacement (1996:337).

This sketch is suggestive of the dynamics that were at work in Treptow an der Rega and in the abbeys. That Elisabeth von Meseritz was stirred by these and other teachings is evident in her decision to leave the convent.

\section{Single in Wittenberg and its Lutheran Reformation}

When Elisabeth von Meseritz came to Wittenberg in 1521 or 1522 it already was a town deeply infected by reformational principles formulated by Martin Luther and others. Clearly she was no stranger to the principle of religious reform, nor

23.In this writing 'Luther wrecks the doctrinal structure of the papacy down to its very foundations' and as consequence Bugenhagen exclaims 'The whole world is blind and living in Cimmerian darkness. This man alone sees the truth' (Ruccius 1925:20; cf. footnote 9).

24.After some mergers with other denomination it is known today as the Pomeranian Evangelical Church, combining both Lutheran and reformed persuasions.

25.See Luther's letter of 15 January 1534 to the Abbess of Hervord about expectations for ministry: 'But we beg your Grace, in what concerns the necessary Church offices, to bear with patience the circumstances of these times, and not to seek your rights too sharply in every thing' (Luther 1865:79). was she a stranger to spiritual songs and its music. Here, in Wittenberg, new songs were being sung attesting to new insights into the Christian faith.

From 1518 to 1525 a number of scholars, amongst others Philip Melanchthon (1497-1560), Justus Jonas (1493-1555) and Johannes Bugenhagen (1485-1558) were attracted to the humanism and theology of the University of Wittenberg (Wengert 2014:491) and not least the new insights of Martin Luther (1483-1546). But life also took its normal course. Johannes Bugenhagen's first attempt to get married failed but he finally married in 1522 to Walpurga.

Bugenhagen later officiated at Luther's wedding in 1525. Elisabeth, whose theology was largely based on Bugenhagen's teaching, must have been encouraged to learn that his private lectures proved to be popular with students. So much so that the faculty of the university approved his Christological interpretation of the psalms and with Melanchthon's backing he was approved as a lecturer ${ }^{26}$ (Ruccius 1925:24, 25). Some Lutheran theological advances had been made as consequence of Luther's tracts against monastic vows and celibacy. When Bugenhagen first read these theses he exclaimed: 'This thing will effect a revolution of the social status' (1925:26, footnote 3). Though regarded as a renegade priest, ${ }^{27}$ Elisabeth nevertheless must have been well aware of the changes that her former mentor had brought about in his appointment as pastor of the parish church of Stadtkirche (Church of St. Mary) in 1523. He organised pastoral work in the form of care for the poor, visitation of the sick and in prison even to the extent of having instructions for the care of the unfortunate $(1925: 32,38)$. It was the reformational emphasis on love rather than good works that motivated these public services (1925:39). Luther at the time (1522) was preaching his Lenten Invocavit sermons in response to the turmoil caused by Karlstadt's radical support of the immediate abolition of Roman practices (Pelikan \& Lehman 2002). His Septembertestament [New Testament] was published in September 1522 (Burger 2014:483).

When Elisabeth von Meseritz fled the cloister and found her way to Wittenberg she became part of the Bugenhagen household. She knew that contrary to her former catholic teaching in Wittenberg the Lutheran Reformation brought different views to bear on marriage and the priesthood of believers. These considerations were possible because marriage was not regarded as a sacrament in the Wittenberg theology.

One of the women she met was Katharina von Bora (1499-1552) ${ }^{28}$ a former Cistercian nun from 1515-1523 who entered a nunnery after her mother's death. After her escape

26.Junghans (2003) says: "Luther, Jonas, Bugenhagen, and Melanchthon are the reformers of the core group in Wittenberg, who develop protestant theology through their fruitful collaborations and shape the protestant church order through their participation in church and school visitations' (p. 30).

27.Justus Jonas (1493-1555) was another 'renegrade priest' who soon got married after Luther's published pamphlet.

28. Luther's 'chain' was the mother of the Reformation, also called 'Mrs. Reformation' (VanDoodewaard 2013) 
together with eight other nuns from the Cistercian cloister of Nimbschen near Grimma, she worked as a domestic servant and by that learned the intricacies of managing a household. She fell in love but the family was dubious about her background and a possible match was thwarted. Elisabeth also got to know the circle of reformers and met a reformer and a scholar and disciple of Luther, Caspar Cruciger.

Caspar arrived in Wittenberg providentially. His parents escaped the plague raging in Leipzig. He soon distinguished himself as a student and captured Melanchthon's attention (Wengert 2014:492). It is probable that Elisabeth von Meseritz composed a hymn in 1524 the same year the former nun married Caspar Cruciger (known as 'the elder'), in a ceremony officiated by Luther. Two children were born to them, viz. Elisabeth Cruciger the younger, (who married Rector Kegel and on his death, Hans Luther) and Caspar Cruciger, the younger.

For the renegade nun to renege on her vows of chastity was a serious matter. But in Wittenberg she found peace about the matter. For the reformers marriage was a matter of theology but for the Catholics it was about morality (Fudge 2003:319). This was a new role for the former nun. She entered into the role of a scholar and pastor's wife, ${ }^{29}$ as did Katharina von Bora $^{30}$ a year later; the same year the protestant prince Frederick the Wise died. But these women's stories differed somewhat and Katharina's is more explicitly recorded..$^{31}$

Katharina modelled her wifely ministry in pouring her energy into her household and husband, her theological comprehension $^{32}$ implicit rather than explicit (Stjerma 2009:36), though she was not a stranger to conversation (Luther 1865:370 DCCCCXV). In Wittenberg the apostolic and episcopal call of the protestant faith was visibly implemented by pastors' wives at home, involving them in the task of discipling their children (Stjerma 2009:37). Unlike Elisabeth Cruciger (Hendrix 1995:186) and Walpurga Bugenhagen who got on well with Kate Luther, Melanchthon's wife, Katharina Krapp, (married 1520) was resentful of the lesser esteem that she shared with her husband (Ruccius 1925:130, footnote 30). Melanchthon, famously called his home 'a little church of God'.

Probably because Caspar was initially a humanist it was decided to facilitate his maturation as theologian. To gain practical experience in teaching and evangelical ministry he (and by implication his wife) was sent to Amsdork to teach 29.One of the first 'evangelischen Pfarrfrauen'.

30.The marriage of renegade priest and nun invoked violent responses. Thomas More for instance viewed broken vows an indictment on protestant theology serving to discredit it in contrast to Luther's view that it served as a firm witness to the gospe (Fudge 2003:345).

31.It is said that Luther, determined to marry 'to spite the devil and the pope, please my father, and set an example', married her. Katharina Luther responded a bit differently days after her wedding: 'I have to train the doctor a little differently so that he does what I want' (Mattox 2003:67, footnote 1).

32.Some women, for instance Argula von Grumbach were actively involved in promoting and defending the Reformation. Magdalene Heymair (c. 1530-1586) in Augsburg rewrote the epistles in song to make them comprehensible for children (Wilson 1991:557-558) in an instruction manual. at a Latin school, the Magdeburg's Johannisschule (Wengert 2014:392). It is not without significance that the plague (Black Death) struck Wittenberg in $1527 .{ }^{33}$ Imperilling their lives Luther and Kathe stayed in the town to minister to the sick. ${ }^{34}$ The Cruciger's returned in 1528; Caspar to teach New Testament and Philosophy at the university and serve as preacher.

Associated with his teaching appointment was that of preacher of the Castle Church congregation. Elisabeth had to adjust to her husband's call and duties. She was the wife of a prominent Wittenberg reformer and preacher, a confidant of Luther and who shared in the scrutiny that comes from the public when a pastoral couple fulfil a visible position in public. In 1533, Elisabeth's husband had the distinction of being promoted Doctor of Theology at the University of Wittenberg. ${ }^{35}$ He was joined by Johannes Bugenhagen and Johannes Aepinus (Johann Hoeck, 1499-1553). They were the first protestant Doctors of Theology (Nieden 2006:46ff.). Credibility of the new doctorate was ensured with the approval of Frederick III, elector of Saxony.

Elisabeth Cruciger died in 1535 in Wittenberg. She was about 35 years old. ${ }^{36}$ However, that is not the end of her story. The legacy she left in the form of a Lutheran hymn must be considered.

\section{Music, part and parcel of the Lutheran Reformation}

Not only do the consequences of nailing 95 theses to the Schloßkirche's (also known as All Saints' Church) ${ }^{37}$ church door in Wittenberg on 31 October 1517 still ripple into the third millennium ${ }^{38}$ so do the hymns that were written during that time. The Reformation affected the daily living: 'Our loving Lord God wills that we eat, drink, and be merry, making use of his creatures, for therefore he created them' (Luther 2004:51 C). ${ }^{39}$ Lutheran participation in worship reflected their founder's musical ability and training. His doctrine of the priesthood of believers was accompanied by the desire to reformulate the church of the 16th century to reflect that of the first (Spelman 1951:166). Luther's opinion

33.To all intents and purposes Saxony was Protestant by the end of 1527.

34.Luther's best known song, 'Ein feste Burg ist unser Gott' [A mighty fortress is our God], resulted from this experience (Leaver 1994:1280-1281). Grew (1938:73) questioned whether the tune to the hymn originated with Luther or became associated with him.

35.The university exercised a powerful attraction due to its evangelical ideas (Scribner 1987:130).

36.That Caspar Cruciger maintained his standing with Luther is evident from being a signatory of Luther's will in 1542 (Luther 1865:123).

37.Frederick the Wise (1463-1525) housed his vast collection of questionable relics which eventually totaled close to 20000 . Prized amongst these were fragments of wood from Noah's ark and Jesus' crib, soot from the furnace into which the three young men were cast in Babylon, a twig from the burning bush and milk from the virgin Mary, most of which allegedly supposedly associated with some spurious apotropaic power. Significant in popular or folk religion pandering to the religious superstitions of the laity (cf. Scribner 1987 on popular religion and the Reformation as 'ritual process').

38.See the initial reaction to them early in November 1517 (Smith 1913:63-64, letter 42 ). On the annual reformation festival in Lutherstadt Wittenberg, especially on reformation day, the town is filled with music.

39.Contrast this to CXVII 'The devil, too, has his amusement and pleasure, which consists in suppressing God's work' (Luther 2004:55, CXVII). 
of music was: 'Music is a fair and sweet gift of God. It has often given to me new life, and inspired me with a desire to preach' (1951:167, footnote 4). ${ }^{40}$ In fact Spelman (1951:168) regards music as the dominant art form of Reformation Germany (cf. also Burger 2014:485), the 'Ein' fest Burg' being the battle hymn of the Reformation. Indeed, Spelman (1951) notes:

The emotional appeal of the Lutheran Chorale with its combination of a strong forceful text and a rugged melody probably had more to do with the first success of the Reformation movement than all the theological arguments. (p. 168)

Contextually this implied that clear cut theology accompanied the singing of these songs, already evident in the 1524 publication of the Wittenbergisch Geistlich Gesangbuch ${ }^{41}$ (Spelman 1951:168). Music had Luther's approval ${ }^{42}$ for it was conducive to 'fullness and joy of life are deemed praiseworthy and desirable possessions' (Grew 1938:67).

Wherever the Lutheran Reformation found a foothold the mission of reforming cities and ecclesial institutions had a profound influence on one another. Not least was the 'spread of the Wittenberg message through their hymns' ${ }^{\prime 3}$ (Kolb 2009:89). Whilst Luther had a profound influence in this regard (Jenny 1985), Elizabeth Cruciger also put a pen to paper and wrote three hymns. 'Music does not happen in a vacuum, but always in context and with an established meaning attributed by society within a given cultural setting' (Doukhan 2010:139). This suggests that the cultural setting in Wittenberg was conducive to creativity when it came to music.

That Luther regarded it as a spiritual matter is clear from the following. He was persuaded regarding the spiritual usefulness of music ${ }^{44}$ in the vernacular and in the church. Doukhan (2010) reports Luther's attitude:

I am not ashamed to confess publicly that next to theology there is no art which is the equal of music, for she alone, after theology, can do what otherwise only theology can accomplish, namely, quiet and cheer up the soul of man. (p. 162, footnote 5)

Luther 'saw in it a venue to get in touch with the transcendental, divine wisdom' (Doukhan 2010:189) and said, 'I wish to make hymns for the people so that the word of God may dwell in their hearts by means of song, and so

\footnotetext{
40.Spelman (1951:166-167) also extends the quote to include Augustine's guilt at enjoying music, and Jerome's condemnation thereof. In this instance Luther's dual principles seem to have been a blend of, if it was in the Bible or not condemned principles seem to have been a blend of, if it was in the Bible or not condemned
or contradicted it, a matter was to be regarded favourably. Luther was 39 when he started to address the music aspect of the church (Grew 1938:71)

41.There is so much published year by year on Luther's hymns that not even the annual bibliography of the Lutherjahrbuch can offer a complete overview of publications (Burger 2014:486)

42.At the University of Erfurt in 1501 he was popularly known as 'the philosopher and the musician' (Grew 1938:70).

43.John Wycliffe initiated a debate of the place of music in church about 130 years before Luther broached the subject. This is a debate still active in the church, especially amongst evangelicals. Luther saw music as applied in church on the levels of folk and art music. He brought music back from the sacred to the everyday experience of the people (Doukhan 2010:189-190, 162).

44.'The tunes of Luther are, like his hymns, fundamentally German ... words and music are ideally matched' (Grew 1938:74).
}

that they may address God in a language they understand' (Grew 1938:71). The Word (gospel) in song and music ${ }^{45}$ preached to all and sundry. Luther (1872:265 DCXIX) also believed that 'Our songs and psalms sorely vex the devil'46 who cannot stand rejoicing and flees music 'for the evil spirit is ill at ease wherever God's Word is sung or preached in true faith' (Doukhan 2010:189, footnote 106 \& 107). Luther had a dream to bring music into the church and Elisabeth to preach (Grüneklee 2012b). A later story about a dream, probably fictitious, recounts that Elisabeth saw herself preaching. Her husband, Caspar, it is said, interpreted it that her songs would be sung in churches (Haemig 2001:41ff., footnote 102).

Another echo of this view of preaching theology in song was Paul Speratus (1483-1551). It was probably during his Moravian imprisonment, that he wrote Es ist das Heil uns kommen her [Salvation unto us has come] in 1523 (Hendrix 1995:185). This is a hymn known for its focus on personalising the message of Luther's theology. Present day opinion supports this purpose of church music (1995:185). Doukhan $(2010: 42-46,137)$ sees the purpose and role of sacred music as a vehicle to convey theology, for expression and communication, and defined within the cultural setting becomes a delight to God. But there is also the consideration that the words of hymns intensify the joy of their enjoyment as the intension of their words become clearer, as Luther found (Grew 1938:78). This leads Doukhan (2010:137) to consider the question: 'What does it mean, then, to reflect the image of the Creator in music, and how can we achieve this goal?' Her answer is that 'a true Christian life' reflecting God-like attitudes will reflect that. It is not unreasonable to conclude that Elisabeth von Meseritz (Cruciger) had ample of such examples during her sojourn in Wittenberg. Consequently writing a hymn would simply reflect her passion for $\operatorname{God}^{47}$ that was already evident in her life, which was enough to convince Caspar Cruciger that he was marrying a true believer persuaded by the Lutheran Reformation.

The first Lutheran hymnal 'Etlich Cristlich lider, Lobgesang un Psalm' [Some Christians songs, worship songs and Psalms; RP translation] was published in 1524 and contained eight songs $^{48}$ affirming Wittenberg reformation theology. When the hymn 'Herr Christ der einig Gottes Sohn' [Lord Christ the only Son of God] (Evangelisches Gesangbuch n.d.) ${ }^{49}$ appeared in 1524 under the title 'Eyn Lobsanck vom Christo'

45. Luther wrote 36 hymns which in time became a national possession 'so that his enemies said he had destroyed more souls by them than by all his speeches and other writings' (Grew 1938:72)

46.Amongst his friends Luther was nicknamed 'die wittenbergische Nacthigall' [the Wittenberg nightingale] (Grüneklee 2012a:1).

47.This may be compared to the earlier 'plague hymn' written by 1519 by Ulrich Zwingli. From this hymn Locher (1981:152) is persuaded that one may discern a deep 'personal faith in divine providence and a readiness to offer himself as an instrument of God'. This near death experience affected him deeply and allowed him to be completely reliant upon God, as Elisabeth was upon leaving the convent.

48. Hence called the Achtliederbuch; four were written by Luther, three by Paul Speratus (1484-1551).

49.This hymn is regarded as belonging to Epiphany in the church calendar 
in the Erfurt Enchiridion ${ }^{50}$ it was the only one by a woman ${ }^{51}$ (Haemig 2001:21, footnote1 \& 2) though initially credited as anonymous. ${ }^{52}$ Nevertheless it was widely known to have been the work of Elisabeth Cruciger (2001). No stranger to spiritual songs, Elisabeth must have learnt a number as a child and more during her stay in the convent as a nun. But this composition was different. It expressed her new found faith and the challenge of the 95 theses seven years earlier, ${ }^{53}$ in particular the fourth verse of the hymn. She would never have the exposure she had as a nun to public ministry in Lutheran Protestantism, but her hymn would be announced from pulpits and be sung in churches in Germany and beyond $^{54}$ (Adam et al. 2012:14).

There is some attribute to 'Elisabeth M.' (Meseritz?) in 1528 but in 1529 her full married name gets credited to the hymn. ${ }^{55}$ However, it was only from 1531 that composition of the hymn is regularly accredited to her. ${ }^{56}$ Elisabeth Cruciger's hymn reveals some implicit information about her: She is persuaded that the Lutheran Reformation is a return to the convictions of the Early Church and not to Rome.

The third stanza of the hymn reads: 'so, daß wir hier mögen schmecken dein Süßigkeit im Herzen und dürsten stets nach dir' [that your sweetness may be tasted in our hearts which constantly thirst for you - RP interpretation]. Some see this as seminal residue of Catholic contemplative mysticism. ${ }^{57}$

The stanzas have been interpreted to convey ${ }^{58}$ the following (Grüneklee 2012b):

- Stanza 1: solus Christus (only Christ or Christ alone).

- Stanza 2: Christ's work is considered.

- Stanza 3: Petition to the Holy Spirit to minister to the dual opposites of taste-thirst, a longing for the coming kingdom of God.

50.It is printed in Geystliche gesangk Buchleyn [spiritual songbook] under the title 'Eyn Lobsanck von Christo' [Song to the praise of Christ]. See the Evangelishces Gesangbuch und Gotteslob online.

51.Other contributers were Luther (18), Paul Speratus (3), Justus Jonas (1 or 2), Erhard Hegenwald and Jan Hus (one each).

52.For a discussion of the reasons for anonymity and further complications about reasons for continued debate about the hymn's authorship, cf. Haemig (2001) Haemig seems to continue the uncertainty of the authorship of 'Herr Christ der einig Gottes Sohn'.

53.See for instance Markus Jenny (1962:245, referred to in Haemig 2001:21, footnote 1).

54.It is sung in particular the Sunday after Epiphany.

55.There are differing views on whether she wrote the hymn before or after her marriage (Haemig 2001:32). The author of this article's opinion, formed from reading is that she probably wrote it before she was married. Her dream about 'preaching' also emphasises her love of singing in the home.

56.This late accredition is a reminiscent of carving a women's role. Katherina Zell powerfully expressed in reaction to' those who criticised her public ministry Addressing the immoral behaviour of catholic priests, she (quoted in Head 1990) says: 'You remind me that the apostle Paul told women to be silent in church. would remind you of the word of this same apostle that in Christ there is no longer male nor female' [Gal. 3:28] and of the prophecy of Joel [2:28-9]: 'I will pour forth my spirit upon all flesh, and your sons and your daughters will prophesy.' I do not pretend to be John the Baptist rebuking the Pharisees. I do not claim to be Nathan upbraiding David. I aspire only to be Balaam's ass, castigating his master' (p. 159). Luther also mentions her as the author of the hymn (Haemig 2001:37, footnote 84).

57.It is a common practice of medieval spirituality.

58.This is a brief summary of the article on the stanzas as analysed by Grüneklee (2012b).
- Stanza 4: Power of the continued message God is impressing upon his people.

- Stanza 5: Justification is by faith alone and undergirds repentance.

The non-conformist William Jenkyn (1612-1685) stated incisively, almost a hundred years later that 'praise shall conclude that work which prayer began' (Goldie \& Spurr 1994:579 \& footnote 2).

Though innovative it is a far cry from Leonard Sweet's SoulTsunami (1999) suggesting that the church is not surviving the postmodern culture. To validate the God-experience he suggests the addition of sensory experiences of feel, taste, touch, hear and smell, and music forms an element of the experience. Five hundred years earlier, Elisabeth Cruciger was persuaded to know and experience God in the power of the Spirit in worship through composing a hymn.

\section{Conclusion}

When it comes to making life changing decisions, Elisabeth Cruciger, née von Meseritz, is an example of responding to God by faith. She bucked the church's institution of the security of a convent and arrived single in a foreign town full of dynamic church changes and debate. She got married and together with her husband, Caspar, they must be seen as reformers. They were a couple undivided in their promotion of the Reformation, each following the path in which their gifts allowed them to serve.

The role of music in church worship has changed from a past elevation of a mystic element in music to present day tolerance (Doukhan 2010:182). That it ought to be subservient to the Word is what we learn from Elizabeth Cruciger. That it reflects confessional and creedal truths did not inhibit her for songs to unite the participation of the worshipers within and without the church.

'Today's youth are, on the contrary, expecting a real and lasting message, even if it is a difficult one' (Doukhan 2010:137). There is a revival in spirituality and a genuine seeking for an encounter with God not least added depth to the spiritual journey that they embarked upon. Five hundred years earlier Elizabeth Cruciger's lifestory gave evidence of this in her generation.

\section{Acknowledgements Competing interests}

The author declares that he has no financial or personal relationship(s) that may have inappropriately influenced him in writing this article.

\section{References}

Adam, U., Menz, M., Hinze, A., Bartels, M., Rühle, P. \& Ehrlich, S., 2012, Die Süßigkeit des Glaubens, Rogate frauentreffen 2012 Kirchliche Frauenarbeit der Ev. - Luth. Landeskirche Sachsens, pp. 1-28, viewed 19 November 2014, from http://www. frauenarbeit-sachsen.de/mat/rogate2012.pdf 
Aikin, J.P., 1989, Scaramutza in Germany: The dramatic works of Caspar Stieler, Pennsylvania State University Press, University Park.

Bainton, R.H., 2013, Here I stand: A life of Martin Luther, Abingdon, Nashville.

Burger, C., 2014, 'Luther's thought took shape in translation of Scripture and hymns', ch. 35', in R. Kolb, I. Dingel \& L. Batka (eds.), The Oxford handbook of Martin Luther's theology, pp. 481-490, Oxford University Press, Oxford.

Classen, A. \& Settle, T.A., 1991, 'Women in Martin Luther's life and theology', German Studies Review 14(2), 231-260, viewed 21 February 2014, from http://www.jstor org/stable/1430561

Doukhan, L., 2010, In tune with God, Autumn House Publishing, Hagerstown.

Erikson, E.H., 1993, Young man Luther: A study in psychoanalysis and history, Norton, New York.

Evangelisches Gesangbuch n.d., Liederbuch de christliche Liederdatenbank, viewed 20 October 2015, from http://www.liederdatenbank.de/songbook/8984

Fudge, T.A., 2003, 'Incest and lust in Luther's marriage: Theology and morality in reformation polemics', The Sixteenth Century Journal 34(2), 319-345. (Marriage in early modern Europe).

Gilligan, C., 1982, In a different voice, Harvard University Press, Cambridge.

Goldie, M. \& Spurr, J., 1994, 'Politics and the restoration parish: Edward Fowler and the Struggle for St Giles Cripplegate', The English Historical Review 109(432), 572 the Struggle for St Giles Cripplegate', The English
596. http://dx.doi.org/10.1093/ehr/CIX.432.572

Grew, E.M., 1938, 'Martin Luther and music', Music \& Letters 19(1), 67-78, viewed 12 November 2014, from http://www.jstor.org/stable/727986

Grüneklee, U., 2012a, Reformatorinnen und ihre Lieder: Morgenandacten auf NDR Kultur und NDR Info, Dienstag 29.5-Samstag 2.6.2012, viewed 21 November 2014 from http://www.theologinnenkonvent.de/Frauen-Reformation/Grueneklee,\%20 Reformatorinnen\%20und\%20ihre\%20Lieder.pdf

Grüneklee, U., 2012b, 'Elisabeth Cruciger', Musik und Gender im Internet (MUGI), Lexikon, Multimedia, viewed 13 November 2014, from http://mugi.hfmthamburg.de/Artikel/Elisabeth_Cruciger

Haemig, M.J., 2001, 'Elisabeth Cruciger (1500?-1535): The case of the disappearing hymn writer', The Sixteenth Century Journal 32(1), 21-44. http://dx.doi. org/10.2307/2671393

Harris, B.J., 1993, 'A new look at the Reformation: Aristocratic women and nunneries, 1450-1540', Journal of British Studies 32(2), 89-113. http://dx.doi. org/10.1086/386024

Head, T., 1990, 'The religion of the Femmelettes: Ideals and experience among women in fifteenth- and sixteenth century France', in L.L. Coon, K.J. Haldane \& E.W. Sommer (eds.), That gentle strength: Historical perspectives on women in E.W. Sommer (eds.), That gentle strength: Historical perspectives on
Christianity, pp. 149-175, University Press of Virginia, Charlottesville.

Hendrix, S., 1995, 'Masculinity and patriarchy in reformation Germany', Journal of the History of Ideas 56(2), 177-193, viewed 12 September 2014, from http://www. History of Ideas $56(2), 177-$
jstor.org/stable/2709834

Holt, M.P., 2003, 'The social history of the Reformation: Recent trends and future agendas', Journal of Social History, 37(1), 133-144, Special issue (Autumn), viewed 12 September 2014, from http://www.jstor.org/stable/3790318

Jenny, M. (ed.), 1985, 'Luthers geistliche Lieder und Kirchengesänge', suppl. to vol. 35 of the Weimar edition of Luther's works, Gerhard Ebeling (ed.), Böhlau Verlag, Cologne.

Junghans, H., 2003, 'Luther's Wittenberg', in D.K. McKim (ed.), The Cambridge companion to Martin Luther, pp. 20-36, Cambridge University Press, Cambridge.

Karant-Nunn, S.C. \& Wiesner-Hanks, M., 2003, Luther on women: A sourcebook, Cambridge University Press, Cambridge.

Kolb, R., 2009, Martin Luther: Confessor of the faith; Christian theology in context, Oxford University Press, Oxford.

Leaver, R.A., 1994, 'A mighty fortress is our God', in R.F. Glover (ed.), The Hymnal 1982 Companion, vol. 3b, pp. 1280-1281, The Church Hymnal Corporation, New York.
Locher, G.W., 1981, Zwingli's thought: New perspectives, Brill, Leiden.

Luther, M., 1865, Luther's letters to women, collected by K. Zimmerman, Chapman \& Hall, London.

Luther, M., 1872, The table talk of Martin Luther, transl. W. Hazlitt (ed.), Bell \& Daldy, London.

Luther, M. 2004, Table talk, transl. W. Hazlitt (ed.), viewed 21 November 2014, from http://www.ccel.org/ccel/luther/tabletalk.html

Mattox, M.L., 2003, Defender of the most holy matriarchs: Martin Luther's interpretation of the women in Genesis in the 'Enarratines in Genesin', 1535-1545, interpretation
Brill, Leiden.

McAdams, D.P., 1988, Power, intimacy, and the life story: Personological inquiries into identity, Guilford Press, New York.

McNamara, J.A.K., 1996, Sisters in arms: Catholic nuns through two millennia, Harvard University Press, Cambridge.

Moeller, B., 1972, Imperial cities and the Reformation: Three essays, transl. H.C.E. Midelfort \& M.U. Edwards, Jr. (eds.), Fortress, Philadelphia.

Nieden, M., 2006, Die Erfindung des Theologen: Wittenberger Anweisungen zum Theologiestudium im Zeitalter von Reformation und Konfessionalisierung, Spätmittelalter und Reformation, Mohr Siebeck, Tübingen.

Pelikan, J. \& Lehman, H.T. (eds.), 2002, 'Eight sermons at Wittenberg 1522', Luther, vol. 51, Sermons, 55 Volume American Edition: Luther's Works, CD-ROM, Fortress, Concordia Publishing House, St. Louis.

Po-Chia Hsia, R., 1987, 'The myth of the commune: Recent historiography on city and Reformation in Germany', Central European History 20(3-4), 203-215. http:// Reformation in Germany', Central Europ
dx.doi.org/10.1017/S0008938900012061

Potgieter, R., 2014, 'The emergence of John Calvin as pastoral figure from his letters', In die Skriflig 48(1), Art. \#1829, 9 pages. http://dx.doi.org/10.4102/ids.v48i1.1829

Ruccius, W.M., 1925, John Bugenhagen Pomeranus, a biographical sketch, United Lutheran Publication House, Philadelphia.

Scribner, R.W., 1987, Popular culture and popular movements in Reformation Germany, Hambleton, London.

Smith, P. (ed.), 1913, Luther's correspondence and other contemporary letters, vol. 1, pp. 1507-1521, Lutheran Publication Society, Philadelphia.

Spelman, L.P., 1951, 'Luther and the arts', The Journal of Aesthetics and Art Criticism, 10(2), viewed 12 November 2014, from http://www.jstor.org/stable/426851

Spierling, K., 2012, 'Women, marriage and family', in D. Whitford (ed.), T\&T Clark companion to reformation theology, pp. 178-196, Clark, New York.

Stjerna, K., 2009, Women and the reformation, Blackwell, Oxford.

Sweet, L., 1999, SoulTsunami: Sink or swim in a new millennium culture, Zondervan, Grand Rapids.

VanDoodewaard, R., 2013, 'Mrs. Reformation: The life of Katharine Luther, a review of the Mother of the Reformation; The amazing life and story of Katharine Luther', in The Aquila Report, Reformed Theological Seminary, viewed 13 November 2014, from http://theaquilareport.com/mrs-reformation-the-life-ofkatharine-luther/

Wengert, T.J., 2014, 'The Wittenberg Circle', in R. Kolb, I. Dingel \& L. Batka (eds.), The Oxford handbook of Martin Luther's theology, pp. 491-501, Oxford University Press, Oxford.

Whitford, D.M., 2012, 'Studying and writing about the Reformation', in D.M. Whitford (ed.), T\&T Clark companion to reformation theology, pp. 3-13, Clark, New York.

Wilson, K.M. (ed.), 1991, 'Magdalena Heymair (or Heymarin)', in An encyclopedia of continental women writers, 1: A-K, pp. 557-558, Garland, New York. (Garland reference library of the humanities).

Zook, M.S., 2002, 'Integrating men's history into women's history: A proposition', The History Teacher 35(3), 373-387, viewed 17 November 2014, from http://www. jstor.org/stable/3054443 